\title{
Functional comparison between the human inferior epigastric artery and internal mammary artery
}

\author{
Similarities and differences
}

Although the inferior epigastric artery has been used as an alternative arterial graft for coronary artery bypass grafting, little is known about the contractile and relaxation characteristics of this artery. This study was designed to compare the pharmacologic reactivity of the two arterial conduits-the inferior epigastric artery and the internal mammary artery. Forty-one inferior epigastric artery ring segments from eight patients undergoing coronary grafting and 62 internal mammary artery ring segments were set up in organ baths under physiologic pressure. The contractility was determined from the contraction induced by the depolarizing agent potassium and receptor-mediated vasoconstrictor agents, norepinephrine, U46619, and endothelin-1. Endothelium-dependent relaxation was induced by the calcium ionophore A23187, a non-receptor agonist for endothelium-derived relaxing factor, and acetylcholine, a receptor agonist for endothelium-derived relaxing factor. Glyceryl trinitrate was used to study endothelium-independent relaxation. The maximal response (either contraction or relaxation) and the effective concentration causing $\mathbf{5 0 \%}$ of the maximal response for these two arteries were compared. There was no difference $(p>0.05)$ either in the maximal contraction force $(5.30 \pm 0.87$ versus $4.76 \pm 0.89 \mathrm{gm}$ for potassium, $5.13 \pm 0.67$ versus $4.47 \pm 1.15 \mathrm{gm}$ for norepinephrine, $8.04 \pm 1.23$ versus $6.23 \pm 0.99 \mathrm{gm}$ for U46619, and $4.88 \pm 0.69$ versus $5.57 \pm 0.93$ for endothelin-1 ( $n=6$ to 10 for each vasoconstrictor) or in the maximal relaxation induced by glyceryl trinitrate $(86.46 \%$ versus $92.98 \%, n=6)$ or by acetylcholine (20.72\% versus $45.51 \%, n=5$ ) between the inferior epigastric artery and internal mammary artery. The effective concentration causing half maximal response to all vasoconstrictors and vasodilators was similar between the two arteries $(p>0.05$ ). However, $\mathbf{A 2 3 1 8 7}$ induced significantly less relaxation in the inferior epigastric artery $(38.42 \pm 15.49 \%, n=6)$ than in the internal mammary artery $(71.89 \pm 7.17 \%$, $n=9, p<0.05$ ). We conclude that contractility, endothelium-independent relaxation, and receptormediated endothelium-dependent relaxation are similar in the inferior epigastric artery and the internal mammary artery. However, the endothelium of this arterial graft has less ability to respond to the non-receptor-mediated endothelium-derived relaxing factor stimulant. The influence of this difference on the prevalence of atherosclerosis and long-term patency rate in the inferior epigastric artery remains to be studied. (J THORAC CARDIOVASC SURG 1995;109:13-20)

Guo-Wei He, MD, PhD, ${ }^{\mathrm{a}, \mathrm{b}}$ Tea E. Acuff, $\mathrm{MD},{ }^{\mathrm{a}}$ William H. Ryan, $\mathrm{MD}^{\mathrm{a}}$ Cheng-Qin Yang, MD, ${ }^{\mathrm{a}, \mathrm{b}}$ and Michael J. Mack, MD, ${ }^{\mathrm{a}}$ Dallas, Tex., and Portland, Ore.

From Cardiothoracic Surgery Associates of North Texas at Medical City Dallas Hospital, ${ }^{\mathbf{a}}$ Dallas, Tex., and the Albert Starr Academic Center for Cardiac Surgery, ${ }^{\mathrm{b}}$ St. Vincent Heart Institute, Portland, Ore.

Received for publication Feb. 7, 1994.

Accepted for publication May 16, 1994.
Address for reprints: Guo-Wei $\mathrm{He}, \mathrm{MD}, \mathrm{PhD}$, Director, Cardiovascular Research, The Albert Starr Academic Center for Cardiac Surgery, St. Vincent Heart Institute, 9155 Barnes Rd., Suite 240, Portland, Ore. 97225.

Copyright (C) 1995 by Mosby-Year Book, Inc.

$0022-5223 / 95 \$ 3.00+0 \quad \mathbf{1 2 / 1 / 5 7 4 3 3}$ 
Although the internal mammary artery (IMA) has been used for coronary artery bypass grafting $(C A B G)^{1-6}$ and has yielded a superior long-term patency rate, the inferior epigastric artery (IEA) has only recently been selected for use as a CABG conduit. $^{7-12}$ Preliminary clinical studies have suggested promising results for this graft, ${ }^{7-12}$ although long-term patency rates are still unknown. In general, knowledge of the biologic characteristics of an arterial conduit is essential to understand its characteristics as a bypass graft. The present study was primarily designed to investigate the contractility, relaxation, and endothelial function of the IEA. The IMA, a well-studied arterial conduit for CABG, is used as a comparison.

\section{Material and methods}

Human IEA and IMA segments were collected from patients undergoing IEA and/or IMA graft operations. Approval to use discarded IEA and IMA tissue was given by the Human Ethics Committee of the Medical City Dallas Hospital. After sternotomy, a full-length left IMA pedicle was carefully dissected from the chest wall. Either the left or the right IEA was mobilized by a method described by Mills and Everson. ${ }^{12}$ The patients were then heparinized and cardiopulmonary bypass was instituted. The left IMA was cut distally and the length for grafting to the left anterior descending artery was carefully measured and preserved. The required length for the IEA was also carefully measured. Any discarded IEA or distal IMA segments were collected and put into a container with oxygenated physiologic (Krebs) solution maintained at $4^{\circ} \mathrm{C}$ and then transferred to the laboratory immediately. The IEA and IMA were transferred into a glass dish and dissected out from their surrounding connective tissue. The arteries were then cut into $3 \mathrm{~mm}$ rings, and the rings were suspended on wires in organ baths. ${ }^{13-15}$ The number of rings taken from each patient varied from two to six. The rings used for the pharmacologic study were taken only from the section that did not show any gross atherosclerosis. The Krebs solution had the following composition (in millimoles per liter): $\mathrm{Na}^{+} 144, \mathrm{~K}^{+} 5.9, \mathrm{Ca}^{2+} 2.5$, $\mathrm{Mg}^{2+} 1.2, \mathrm{Cl}^{-} 128.7, \mathrm{HCO}_{3}{ }^{-} 25, \mathrm{SO}_{4}{ }^{2-} 1.2, \mathrm{H}_{2} \mathrm{PO}_{4}{ }^{-} 1.2$, and glucose 11. The solution was aerated with a gas mixture of $95 \%$ oxygen and $5 \%$ carbon dioxide at $37^{\circ} \pm$ $0.1^{\circ} \mathrm{C}$.

Organ bath technique. An organ bath technique that allowed vascular rings to be normalized to a physiologic condition in vitro was used to set the vascular rings at a pressure comparable with that at the in vivo situation. The details of the technique were published before. ${ }^{15,16} \mathrm{In}$ brief, both the IEA and IMA rings were stretched in progressive steps to determine the length-tension curve for each ring. A computer iterative fitting technique was used to determine the exponential line, pressure, and internal diameter. When the transmural pressure on the rings reached $100 \mathrm{~mm} \mathrm{Hg}$, determined from their own length-tension curves, the stretching procedure was stopped and the rings were then released to $90 \%$ of their internal circumference at $100 \mathrm{~mm} \mathrm{Hg}$. This degree of passive tension was then maintained throughout the experiment.

We intentionally preserved the endothelium by cautiously dissecting and mounting the rings. We previously found that this technique allowed the experiments to be carried out with an intact endothelium, as determined by the functional relaxation response to acetylcholine. ${ }^{14,16}$

Protocol. After the normalization procedure, the IEA and IMA rings were equilibrated for 45 minutes. The following protocols were designed for the experiments.

Contraction. Diameters of the IEA and IMA at a pressure of $100 \mathrm{~mm} \mathrm{Hg}$ were recorded from the normalization procedure. The cumulative concentration-contraction curve was established for the following vasoconstrictor substances: endothelin-1; norepinephrine, a full adrenoceptor agonist; U46619, a stable thromboxane $A_{2}$ mimetic; and a membrane depolarizing agent, potassium chloride.

Relaxation. In this study, both endothelium-dependent and endothelium-independent relaxation were compared in the IEA and IMA. Relaxation was expressed as percentage relaxation of the precontraction induced by U46619 (10 nmol/L).

ENDOTHELIUM-DEPENDENT RELAXATION.

1. Receptor-mediated endothelium-dependent relaxation was induced by acetylcholine, a receptor-mediated endothelium-derived relaxing factor-nitric oxide agonist.

2. Non-receptor-mediated endothelium-dependent relaxation was induced by calcium ionophore A23187 (calcimycin), a non-receptor-mediated endothelium-derived relaxing factor-nitric oxide agonist.

ENDOTHELIUM-INDEPENDENT RELAXATION. Endotheliumindependent relaxation was induced by glyceryl trinitrate.

The reactivity of IEA and IMA was expressed as maximal contraction (or relaxation) and sensitivity. The sensitivity of the IEA and IMA to vasoconstrictor (endothelin-1, norepinephrine, U46619, and potassium) or vasodilator (acetylcholine, A23187, or glyceryl trinitrate) agents is expressed by the effective concentration that induced $50 \%$ of the maximal effect (either contraction or relaxation; $\mathrm{EC}_{50}$ ). The $\mathrm{EC}_{50}$ was determined from each concentration-contraction (or relaxation) curve by a logistic, curve-fitting equation: $E=\mathrm{MA}^{\mathrm{p}} /\left(\mathrm{A}^{\mathrm{p}}+\mathrm{K}^{\mathrm{p}}\right)$, where $\mathrm{E}$ is response, $\mathrm{M}$ is maximal contraction (or relaxation), $\mathrm{A}$ is concentration, $\mathrm{K}$ is $\mathrm{EC}_{50}$ concentration, and $\mathrm{p}$ is the slope parameter. ${ }^{17}$

The unpaired Student's $t$ test was used to compare the contraction force or percentage relaxation for each vasoconstrictor, vasodilator, and the $\mathrm{EC}_{50} \mathrm{~s}$ between the IEA and IMA. A $p$ value less than 0.05 was considered significant.

Drugs. Drugs used in this study and their resources were as follows: acetylcholine, A23187, and norepinephrine bitartrate (Sigma Chemical Co., St. Louis, Mo.); U46619 (Cayman Chemical, Ann Arbor, Mich.); endothelin-1 (Peptides International, Louisville, Ky.); and glyceryl trinitrate (Roussel Canada Inc., Montreal, Quebec, Canada). Stock solution of norepinephrine and acetylcholine was freshly made each day. Stock solution of endothelin-1 and U46619 was held frozen until required. 
Table I. Comparison of the contractility of the IEA and the IMA to various vasoconstrictors

\begin{tabular}{|c|c|c|c|c|c|c|c|c|}
\hline & \multicolumn{4}{|c|}{ Maximal contraction (gm) } & \multicolumn{4}{|c|}{$E C_{50}(-\log M)$} \\
\hline & $K$ & $U 46619$ & $N E$ & $E T$ & $K(\mathrm{mmol} / L)$ & $U 46619$ & $N E$ & $E T$ \\
\hline IEA & $\begin{array}{l}5.30 \pm 0.87 \\
\quad(n=6)\end{array}$ & $\begin{array}{c}8.04 \pm 1.23 \\
(n=6)\end{array}$ & $\begin{array}{c}5.13 \pm 0.67 \\
(n=6)\end{array}$ & $\begin{array}{c}4.88 \pm 0.69 \\
(n=6)\end{array}$ & $14.29 \pm 1.9$ & $8.25 \pm 0.09$ & $6.59 \pm 0.18$ & $8.22 \pm 0.04$ \\
\hline IMA & $\begin{array}{c}4.76 \pm 0.90 \\
(n=14)\end{array}$ & $\begin{array}{c}6.23 \pm 0.99 \\
(n=13)\end{array}$ & $\begin{array}{c}4.47 \pm 1.15 \\
(n=6)\end{array}$ & $\begin{array}{c}5.57 \pm 0.93 \\
(n=6)\end{array}$ & $18.36 \pm 1.80$ & $8.35 \pm 0.09$ & $6.48 \pm 0.24$ & $8.36 \pm 0.11$ \\
\hline$p$ Value & 0.72 & 0.30 & 0.63 & 0.56 & 0.20 & 0.51 & 0.71 & 0.27 \\
\hline
\end{tabular}

$K$, Potassium chloride; $N E$, norepinephrine; $E T$, endothelin-1; $n$, number of ring segments.

\section{Results}

Forty-one IEA rings and 62 IMA rings were studied. The diameter at a pressure of $100 \mathrm{~mm} \mathrm{Hg}$ was $2.02 \pm 0.08 \mathrm{~mm}$ for the IEA and $2.22 \pm 0.07 \mathrm{~mm}$ for the IMA $(p=0.08)$.

Contraction. Table I gives the details of the maximal contraction force and $\mathrm{EC}_{50}$ value induced by endothelin-1, norepinephrine, potassium chloride, and U46619 in IEA compared with IMA. No difference was noted between the IEA and IMA for all these four vasoconstrictors either in the maximal contraction or $\mathrm{EC}_{50}$. The average concentrationcontraction curves for these vasoconstrictors are shown in Fig. 1.

\section{Relaxation}

Endothelium-dependent relaxation. The maximal relaxation induced by acetylcholine was $20.72 \% \pm$ $8.27 \%$ in IEA and $45.51 \% \pm 11.29 \%$ in IMA $(p=$ $0.15)$. A23187 induced significantly less relaxation in IEA $(38.42 \% \pm 15.49 \%)$ than in IMA $(71.89 \% \pm$ $7.17 \%, p<0.05)$. No difference in the $\mathrm{EC}_{50}$ for either acetylcholine $(-6.96 \pm 0.63$ versus $-6.69 \pm$ $0.38 \log \mathrm{M}, p=0.71)$ or $\mathrm{A} 23187(-6.38 \pm 0.47$ versus $-6.88 \pm 0.36 \log \mathrm{M}, p=0.42)$ was noted in the IEA and IMA. Fig. $2 a$ and $b$ shows the average concentration-relaxation curves for acetylcholine and A23187 in IEA and IMA.

Endothelium-independent relaxation. No difference was noted between IEA and IMA in either the maximal relaxation induced by glyceryl trinitrate $(86.46 \% \pm 3.54 \%$ and $92.98 \% \pm 2.45 \%, p=0.14)$ or the $\mathrm{EC}_{50}(-7.22 \pm 1.53$ versus $-7.53 \pm 0.16 \mathrm{log}$ $\mathrm{M}, p=0.81$ ) to glyceryl trinitrate. Fig. 3 shows the average concentration-relaxation curve for glyceryl trinitrate in IEA and IMA.

\section{Discussion}

IMA has been successfully applied in CABG because of its high long-term patency rate over saphenous vein grafts and its safety. ${ }^{1-6}$ This graft has become the most common arterial graft, and IMA grafting is a routine procedure for most cardiac surgeons. Biologic characteristics of this graft such as pharmacologic reactivity have been extensively studied. ${ }^{13-16,18,19}$ In contrast, IEA is a newly suggested arterial conduit for $\mathrm{CABG}^{7}$ and its long-term patency rate is not yet known. Also, little is known regarding its pharmacologic reactivity and endothelial function. Therefore, we designed this study to investigate the pharmacologic reactivity of this graft conduit in regard to the smooth muscle as well as endothelial function. IMA, the well-studied arterial graft conduit, is used as a comparison.

The major findings from this study are as follows: (1) the contractility, receptor-mediated endothelium-dependent relaxation and endothelium-independent relaxation of IEA are similar to those of IMA; (2) the non-receptor-mediated endotheliumdependent relaxation (to the calcium ionophore A23187) is less potent in IEA than in IMA.

In the present study, four vasoconstrictors (endothelin-1, norepinephrine, U46619, and potassium chloride) were used to test the contractility of IEA. Endothelin-1 has been proposed as the most potent vasoconstrictor known. ${ }^{20}$ Elevated plasma level has been measured during cardiopulmonary bypass. ${ }^{21}$ Therefore, this vasoconstrictor may have a pathogenic significance in vasospasm related to cardiac surgery. Norepinephrine was selected for the present study because it is a full adrenoceptor agonist; its effect on human IMA has been extensively studied. ${ }^{13,15,16,22,23}$ The thromboxane $\mathrm{A}_{2}$ mimetic, U46619, was used in this study because this vasoconstrictor is a potent agonist in IMA and, like endothelin-1, elevated plasma level of thromboxane $\mathrm{A}_{2}$ has been found. ${ }^{24,25}$ In addition, the cellular membrane depolarizing agent, potassium ion $\left(\mathrm{K}^{+}\right)$, was also used to study contractility. In all these studies regarding the contractile property of the smooth muscle of the IEA, the artery contracted well, which suggests that IEA is a pharmacologically reactive blood vessel. The similar contraction be- 

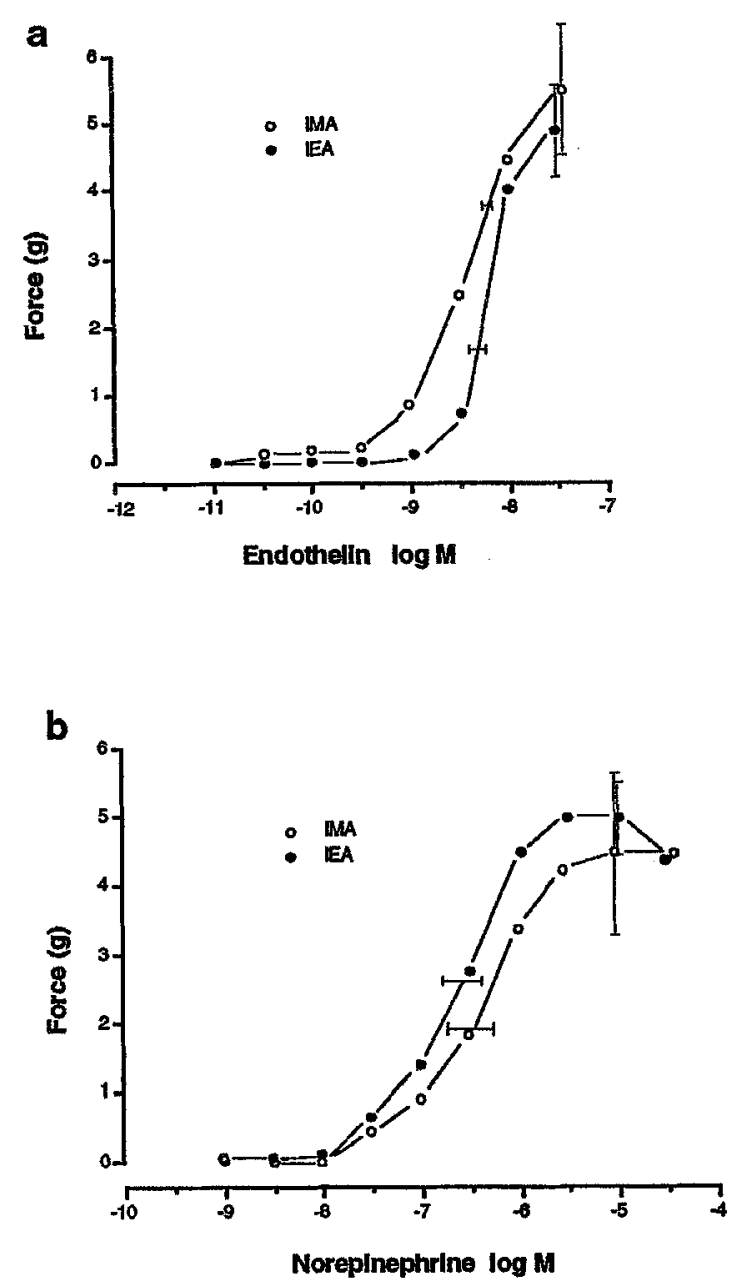
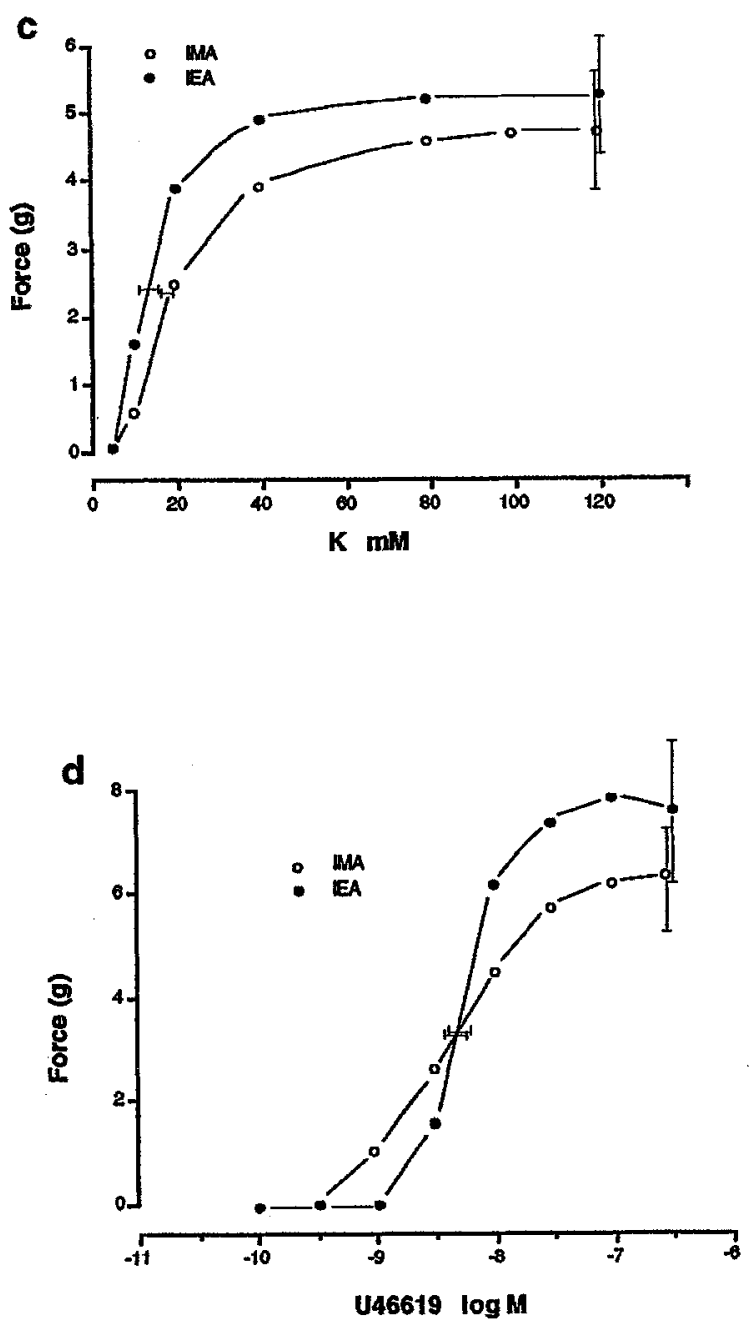

Fig. 1. Mean concentration ( $-\log \mathrm{M})$-contraction (force, g) curves for endothelin-1 (endothelin, a), norepinephrine (b), potassium ( $K, \mathbf{c})$, and $\mathrm{U} 46619$ (d) in the IEA and IMA. Symbols represent data averaged from at least six IEA or IMA rings (see Table I for the number of the rings). Horizontal bars are placed on $\mathrm{EC}_{50}$ values ( \pm 1 standard error of the mean), averaged from logistic, fitted curves from each ring. Vertical bars are 1 standard error of the mean at the maximum response.

tween this artery and IMA is demonstrated in two ways. First, the maximal contraction force between these two arteries is similar for all of the four vasoconstrictors tested (see Fig. 1). Second, the sensitivity of the two arteries to the various vasoconstrictors is also similar, indicated by the similar $\mathrm{EC}_{50}$ to all the four vasoconstrictors tested.

The comparison in regard to the relaxation studies is more complicated than the contraction studies. Vascular relaxation may be classified as endothelium dependent and endothelium independent. In regard to endothelium-independent relaxation, glyceryl trinitrate induced similar relaxation in IEA and IMA. This again suggests that the function of the smooth muscle cells of these two arteries is similar. However, endothelium-dependent relaxation was different in IEA and IMA. The endothelium-dependent relaxation may be evoked by agonists acting on receptors located on the endothelial membrane through endothelium-derived relaxing factor-nitric oxide pathway or other pathways such as endothelium-derived hyperpolarizing factor formation. In the present study, we used acetylcholine, a classic receptor-mediated endothelium-derived relaxing factor agonist, to study endothelium-dependent relaxation. This agonist induced a slightly less, but not statistically significant, relaxation in the IEA than in the IMA. Endothelium-dependent relaxation can 

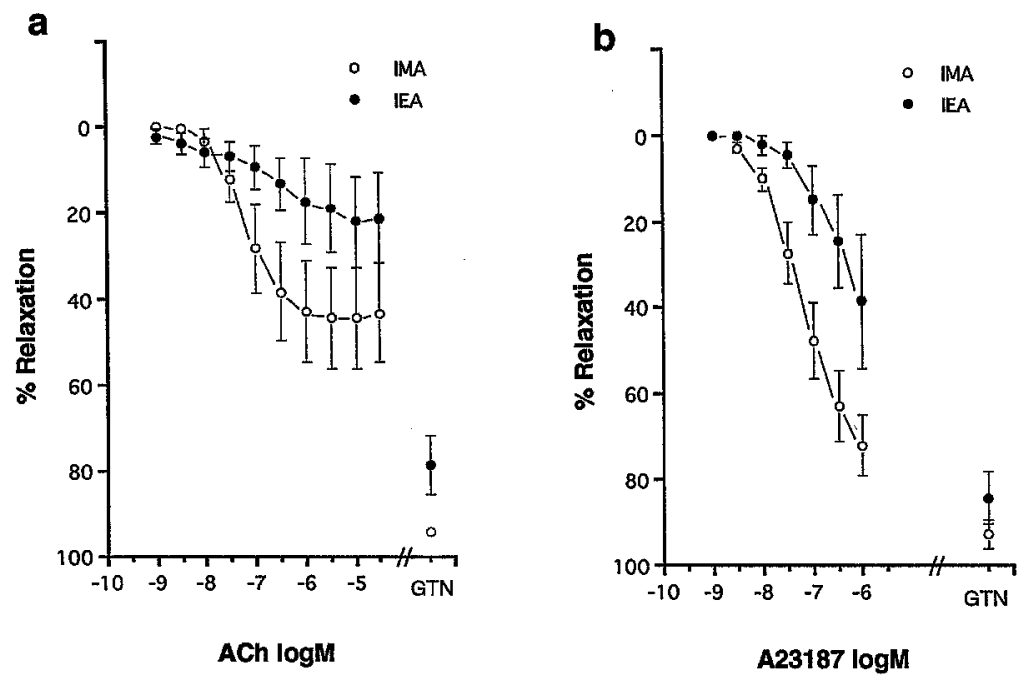

Fig. 2. Mean concentration ( $-\log M)$-relaxation (percent of precontraction) curves for acetylcholine ( $A C h$, a; $n=5$ in each group) or calcium ionophore $\mathrm{A} 23187$ (b; $n=6$ in each group). Symbols represent data averaged from IEA and IMA rings. The precontraction was induced by $\mathrm{U} 46619(10 \mathrm{nmol} / \mathrm{L})$. Vertical bars are 1 standard error of the mean of the response at each concentration.

also be evoked by nonreceptor stimulants such as calcium ionophore A23187. Calcium ionophore increases intracellular calcium level of the endothelial cells through a non-receptor mechanism. The increased intracellular calcium, as the second messenger, modulates the endothelium-derived relaxing factor (nitric oxide) formation, which subsequently relaxes smooth muscle through a cyclic guanosine monophosphate mechanism. In the present study, A23187 induced significantly less relaxation in IEA than in IMA, this is the only significant difference found between these two arteries in terms of pharmacologic reactivity from our study. This finding obviously suggests that the endothelial cells of the IEA have less capacity to release endotheliumderived relaxing factor (nitric oxide) than those of the IMA in response to the stimulation of the calcium ionophore. Because endothelium-derived relaxing factor (nitric oxide) release has been thought to be important to maintain long-term patency, ${ }^{18}$ the influence of this difference on the long-term patency rate of the IEA remains to be studied.

One of the advantages to use of the IMA as a graft is that this artery is usually thought to be free from atherosclerosis. ${ }^{26}$ This well-known characteristic of the IMA may partially account for its high long-term patency rate. However, the prevalence of atherosclerosis of the IEA is still unknown. In our

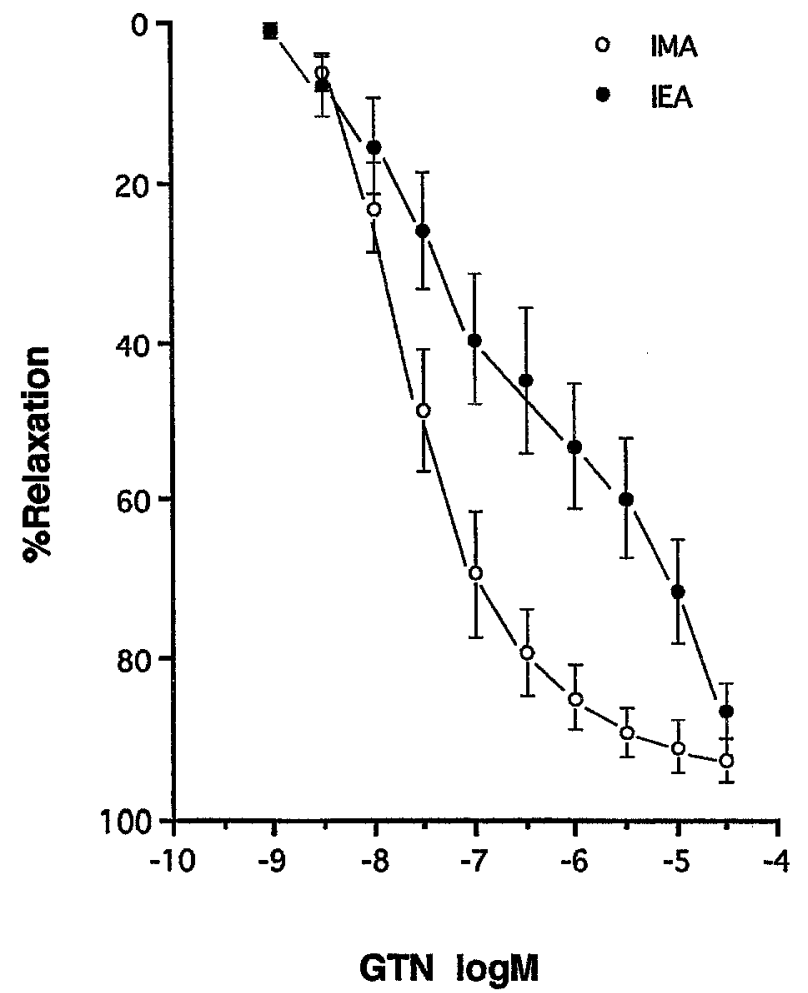

Fig. 3. Mean concentration (-log M)-relaxation (percent of precontraction) curves for glyceryl trinitrate (GTN). Symbols represent data averaged from six IEA and IMA rings. The precontraction was induced by $\mathrm{U} 46619(10 \mathrm{nmol} / \mathrm{L})$. Vertical bars are 1 standard error of the mean of the response at each concentration. 

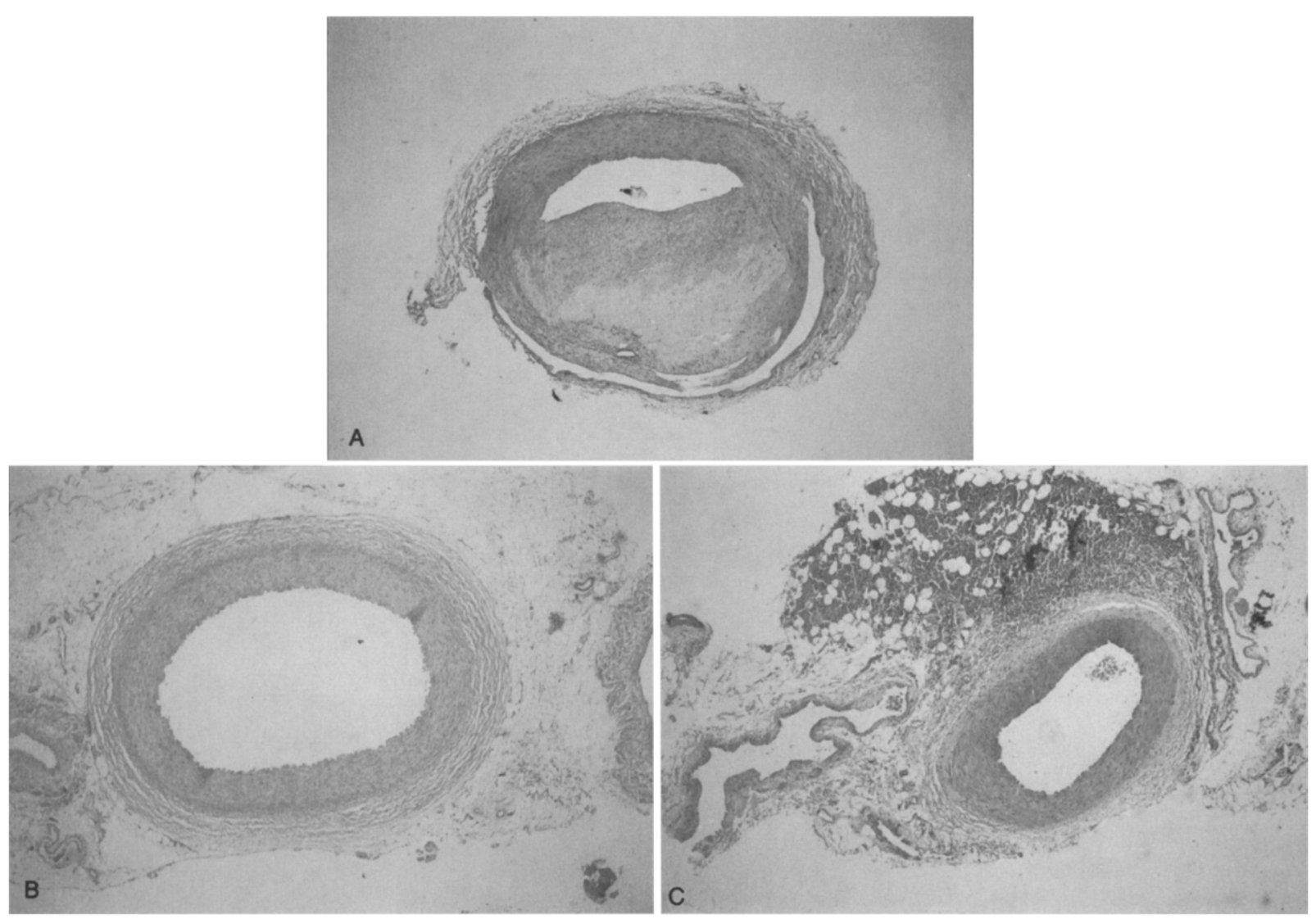

Fig. 4. Photomicrographs of IEA and IMA from one patient. A, Cross section of the IEA with an average diameter of $2.2 \mathrm{~mm}$ demonstrates a prominent eccentric intimal arteriosclerotic plaque with marked thinning of subjacent media. The lumen is narrowed to less than $20 \%$ to $25 \%$ of the expected cross-sectional area. In contrast, the cross section of the left IMA (B) and right IMA (C) demonstrates a normal muscular media with no intimal arteriosclerosis.

practice, we have found that two of the first eight patients undergoing IEA grafting had grossly detected atherosclerosis on the proximal section of the artery. Pathologic study from one of these patients showed that the IEA had a prominent eccentric intimal arteriosclerotic plaque with marked thinning of subjacent media, and the lumen was narrowed to less than $20 \%$ to $25 \%$ of the expected cross-sectional area. Interestingly, although this significant atherosclerotic lesion was seen in the IEA, the IMAs (either the left or the right IMA) of this patient remained free from atherosclerosis as demonstrated in Fig. 4. The fact that in two of eight patients the IEA shows gross atherosclerosis and that the patient whose IEA was atherosclerotic had normal bilateral IMA remained free from atherosclerosis may suggest that atherosclerosis is more prevalent in the IEA than in the IMA. The less potent non-receptor-mediated endothelium-depen- dent relaxation in the IEA, as found in the present study, may imply an early lesion of atherosclerosis. Although the IEA rings used in the present study were free from gross atherosclerosis, some of these segments may have an early atherosclerotic lesion. Others have demonstrated that in atherosclerotic human arteries, stimulated and basal release of endothelium-dependent relaxing factor is impaired ${ }^{27,28}$ and the attenuation of the endotheliummediated vasodilatation is selective. ${ }^{29}$ This is in accordance with our observation in the present study. Our finding of impaired nonreceptor-mediated endothelium-dependent relaxation in the IEA may suggest that decreased endothelium-dependent relaxation may be an early sign of atherosclerosis in the IEA.

In conclusion, we have found from the present study that the pharmacologic reactivity and the size of the human IEA are similar to those of the IMA. 
The only difference between these two arterial conduits in regard to pharmacologic reactivity, found in the present study, is that the IEA has a reduced nonreceptor-mediated endothelium-dependent relaxation. It may be suspected that this reduced relaxation is possibly correlated to early atherosclerosis. The influence of this difference on the longterm patency remains to be studied.

We are grateful to Dr. Wayne E. Taylor for his assistance in pathologic study. We are also grateful to Christine Coleman, RN, and Carol Nicholson, RN, MS, for their valuable technical assistance.

\section{REFERENCES}

1. Loop FD, Lytle BW, Cosgrove DM, et al. Influence of the internal-mammary-artery graft on 10-year survival and other cardiac events. N Engl J Med 1986;314:1-6.

2. Lytle BW, Loop FD, Cosgrove DM, Ratliff NB, Easley K, Taylor PC. Long-term (5-12 years) serial studies of internal mammary artery and saphenous vein coronary bypass grafts. J THORAC CARDIOvASC SURG 1985;89;248-58.

3. Slater $A D$, Gott JP, Gray LA Jr. Extended use of bilateral internal mammary arteries for coronary artery disease. Ann Thorac Surg 1990;49:1014-5.

4. Kirklin JW, Akins CW, Blackstone EH, et al. ACC/ AHA guidelines and indications for coronary artery bypass graft surgery. Circulation 1991;83:1125-73.

5. Landymore RW, Chapman DM. Anatomical studies to support the expanded use of the internal mammary artery graft for myocardial revascularization. Ann Thorac Surg 1987;44:4-6.

6. Tector AJ. Fifteen years' experience with the internal mammary artery graft. Ann Thorac Surg 1986;42: (suppl):S22-7.

7. Puig LB, Ciongolli W, Cividanes GVL, et al. Inferior epigastric artery as a free graft for myocardial revascularization. J THORAC CARdiovasc Surg 1990;99: 251-5.

8. Buche M, Schoevaerdts JC, Louagie Y, et al. Use of the inferior epigastric artery for coronary bypass. $\mathbf{J}$ Thorac Cardiovasc Surg 1992;103:665-70.

9. Paolini G, Mariani MA, Benussi S, et al. Total arterial myocardial revascularization. Eur J Cardiothorac Surg 1993;7:91-5.

10. Barner HB, Naunheim KS, Fiore AC, Fischer VW, Harris $\mathrm{HH}$. Use of the inferior epigastric artery as a free graft for myocardial revascularization. Ann Thorac Surg 1991;52:429-37.

11. Milgalter E, Pearl JM, Laks H, et al. The inferior epigastric arteries as coronary bypass conduits. J Thorac Cardiovasc Surg 1992;103:463-5.

12. Mills NL, Everson CT. Technique for use of the inferior epigastric artery as a coronary bypass graft. Ann Thorac Surg 1991;51:208-14.
13. He G-W, Buxton B, Rosenfeldt F, Angus JA. Reactivity of human isolated internal mammary artery to constrictor and dilator agents: implications for treatment of internal mammary artery spasm. Circulation 1989;80(Suppl):I141-50.

14. He G-W, Angus JA, Rosenfeldt FL. Reactivity of the canine isolated internal mammary artery, saphenous vein, and coronary artery to constrictor and dilator substances: relevance to coronary bypass graft surgery. J Cardiovasc Pharmacol 1988;12:12-22.

15. He G-W, Buxton B, Rosenfeldt F, Wilson AC, Angus JA. Weak $\beta$-adrenoceptor-mediated relaxation in the human internal mammary artery. J THORAC CARDIOVASC SURG 1989;97:259-66.

16. He G-W, Shaw J, Yang C-Q, et al. Inhibitory effects of glyceryl trinitrate on $\alpha$-adrenoceptor mediated contraction in the internal mammary artery. $\mathrm{Br} \mathrm{J}$ Clin Pharmacol 1992;34:236-43.

17. Nakashima A, Angus JA, Jonston CI. Comparison of angiotensin converting enzyme inhibitors captopril and MK421-diacid in guinea pig atria. Eur J Pharmacol 1982;81:487-92.

18. Luscher TF, Diederich D, Siebenmann R, et al. Difference between endothelium-dependent relaxation in arterial and in venous coronary bypass grafts. N Engl J Med 1988;319:462-7.

19. He G-W. Contractility of the human internal mammary artery at the distal section increases toward the end, emphasis on not using the end of the internal mammary artery for grafting. J THORAC CARDIOVASC SURG 1993;106:406-11.

20. Yanagisawa M, Kurihara $H$, Kimura $S$, et al. A novel potent vasoconstrictor peptide produced by vascular endothelial cells. Nature (Lond) 1988;332:411-5.

21. Van Zwienen JCW, Van der Linden CJ, Cimbrere JSF, Lacquet LK, Booij LHDJ, Hendriks T. Endothelin release during coronary artery bypass grafting [Abstr]. Chest 1993;103:176s.

22. He G-W, Shaw J, Hughes CF, et al. Predominant $\alpha_{1}$-adrenoceptor mediated contraction in the human internal mammary artery. J Cardiovasc Pharmacol 1993;21:256-63.

23. He G-W, Acuff TE, Ryan WH, et al. Inhibitory effects of calcium antagonists on $\alpha$-adrenoceptor-mediated contraction in the human internal mammary artery. Br J Clin Pharmacol [In press].

24. Davies GC, Sobel M, Salzman EW. Elevated plasma fibrinopeptide a and thromboxane $\mathrm{B}_{2}$ levels during cardiopulmonary bypass. Circulation 1980;61:803-13.

25. Teoh KH, Fremes SE, Weisel RD, et al. Cardiac release of prostacyclin and thromboxane $\mathrm{A}_{2}$ during coronary revascularization. J THORAC CARDIOvasC SURG 1987;93:120-6.

26. Sims FH. A comparison of coronary and internal mammary arteries and implications of the results in the etiology of arteriosclerosis. Am Heart J 1983;105:560-6. 
27. Chester AH, O'Neil GS, Moncada S, Tadjkarimi S, Yacoub $\mathrm{MH}$. Low basal and stimulated release of nitric oxide in atherosclerotic epicardial coronary arteries. Lancet 1990;336:897-900.

28. Bossaller C, Habib GB, Yamamoto H, Williams C, Wells S, Henry PD. Impaired muscarinic endothelium-dependent relaxation and cyclic guanosine $5^{\prime}$ - monophosphate formation in atherosclerotic human coronary artery and rabbit aorta. J Clin Invest 1987; 79:170-4.

29. Forstermann U, Mugge A, Alheid U, Haverich A, Frolich J. Selective attenuation of endothelium-mediated vasodilation in atherosclerotic human coronary artery. Circ Res 1988;62:185-90.

\section{Bound volumes available to subscribers}

Bound volumes of THE Journal OF THORACIC AND CARDIOVAscular SURGERY are available to subscribers (only) for the 1995 issues from the Publisher, at a cost of $\$ 91.00$ for domestic, $\$ 118.77$ for Canadian, and $\$ 111.00$ for international subscribers for Vol. 109 (January-June) and Vol. 110 (July-December). Shipping charges are included. Each bound volume contains a subject and author index and all advertising is removed. Copies are shipped within 60 days after publication of the last issue of the volume. The binding is durable buckram with the Journal name, volume number, and year stamped in gold on the spine. Payment must accompany all orders. Contact Mosby-Year Book, Inc., Subscription Services, 11830 Westline Industrial Drive, St. Louis, Missouri 63146-3318, USA; phone 1 (800) 453-4351 or (314) 453-4351.

Subseriptions must be in force to qualify. Bound volumes are not available in place of a regular JourNaL subscription. 